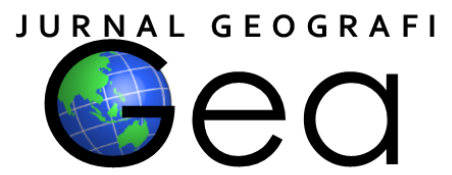

\title{
IDENTIFIKASI KARAKTERISTIK PERMUKIMAN MELALUI SISTEM INFORMASI GEOGRAFIS DI KELURAHAN 1 ULU, KECAMATAN SEBERANG ULU 1, KOTA PALEMBANG
}

\author{
Sri Qodriyati Utami ${ }^{1}$, Aan Suriadi ${ }^{2}$, Eni Heldayani ${ }^{3}$ \\ Program Studi Pendidikan Geografi, Universitas PGRI Palembang, Kota Palembang ${ }^{1,3}$ \\ Program Studi Pendidikan Sejarah, Universitas PGRI Palembang, Kota Palembang ${ }^{2}$ \\ ${ }^{1}$ Tami12672@gmail.com
}

\begin{abstract}
Settlements are a form of various activities of residents above their territory. Variations in each settlement are influenced by physical factors, socio-economic factors and socio-cultural factors. In settlements in urban village 1 which is adjacent to the river Ogan, it has a distinctive appearance to study, but at this time the appearance that is typical of the characteristics of the area is unknown. The purpose of this study was to identify the characteristics of settlements through a geographic information system in Kelurahan 1 Ulu, KecamatanSeberangUlu 1, Kota Palembang. The method used in this research is survey research method. The population in this study were all house buildings in Kelurahan 1 Ulu, Kecamatan Seberang Ulu 1, Kota Palembang. This research sample was made in 4 zones divided by physical boundaries of roads in 1 Ulu Village namely zone 1, zone 2, zone 3 and zone 4. Data was obtained through image interpretation and observation. Data analysis is carried out using a spatial approach. Based on the results of the study, the results were obtained. First, there were variations in the distribution of house buildings, namely Zone 1, Zone 3, and Zone 4, which were Random Settlement Patterns, while Zone 2 was a Group Settlement Pattern. Second, 96.60\% orientation of house buildings facing land or can be called that the direction of the door facing the road instead of the river. Third, Density of House Buildings in 1 Ulu Village with 2 variations namely low and very low zone 1 with $19.5 \% \mathrm{KDB}$ included in the criteria of low density, zone 2 with KDB 3.19\% included in the criteria of very low density, zone 3 with KDB $9.27 \%$ including low density criteria, and zone 4 with KDB $2.17 \%$ including very low criteria. This can be influenced by a factor of 3 factors, which is adjacent to the river, the area that is new and the area that has been long, and transportation and accessibility.
\end{abstract}

Keywords: Characteristics, Interpretation of Images, Geographic Information Systems

\begin{abstract}
ABSTRAK
Permukiman adalah wujud berbagai aktifitas dari penghuni diatas wilayahnya.Variasi setiap permukiman dipengaruhi oleh faktor fisik, faktor sosial ekonomi dan faktor sosial budaya. Pada permukiman di kelurahan 1 Ulu yang berdekatan dengan sungai ogan memiliki kenampakan yang khas untuk dikaji, Namun pada saat ini kenampakan yang khas dari karakteristik wilayahnya belum diketahui. Tujuan dalam penelitian ini adalah untuk mengidentifikasi karakteristik permukiman melalui sistem informasi geografi di Kelurahan 1 Ulu, Kecamatan Seberang Ulu 1, Kota Palembang. Metode yang dipakai dalam penelitian ini adalah metode penelitian survei. Populasi dalam penelitian ini seluruh bangunan rumah di Kelurahan1 Ulu, Kecamatan Seberang Ulu 1, Kota Palembang. Sampel penelitian ini dibuat 4 zona yang dibagi berdasarkan batas fisik jalan di Kelurahan 1 ulu yakni zona 1, zona 2, zona 3 dan zona 4. Data
\end{abstract}


diperoleh melalui interpretasi citra dan observasi. Analisis data dilakukan dengan pendekatan keruangan. Berdasarkan hasil penelitian didapat hasil Pertama, ada variasi sebaran bangunan rumah yaitu Zona 1, Zona 3, dan Zona 4 merupakan Pola Permukiman Acak, sedangkan Zona 2 merupakan Pola Permukiman Mengelompok. Kedua, 96,60\% orientasi bangunan rumah menghadap ke darat atau bisa disebut bahwa arah pintunya menghadap kejalan bukan ke sungai. Ketiga, Kepadatan Bangunan Rumah di Kelurahan 1 Ulu dengan 2 variasi yakni rendah dan sangat rendah zona 1 dengan KDB 19,5\% termasuk ke kriteria kepadatan rendah, zona 2 dengan KDB 3,19\% termasuk ke kriteria kepadatan sangat rendah, zona 3 dengan KDB 9,27\% termasuk kriteria kepadatan rendah, dan zona 4 dengan KDB 2,17\% termasuk kriteria sangat rendah. Hal ini dapat dipengaruhi faktor 3 faktor yakni berdekatan dengan sungai, kawasan yang masih baru dan kawasan yang sudah lama, dan transportasi serta aksebilitasnya.

Kata kunci: Karakteristik, Interpretasi Citra, Sistem Informasi Geografi.

\section{PENDAHULUAN}

Permukiman adalah wujud berbagai aktivitas dari penghuni diatas wilayahnya (Wesnawa, 2015, hal. 83). Bentuk permukiman baik buatan manusia ataupun alami dengan segala kelengkapannya yang digunakan individu manusia maupun kelompok adalah berfungsi untuk tempat tinggal baik sementara maupun menetap dalam rangka menyelenggarakan kehidupannya (Yunus, 1987, dikutip dari Wesnawa 2015, hal. 2). Heldayani (2015, hal. 1) menyatakan bahwa pemilihan atau penentuan lokasi rumah adalah berbeda-beda sesuai dengan pertimbangan masing-masing individu maupun kelompok, salah satu konsekuensi dari adanya pertimbangan tersebut adalah terbentuknya susunan bangunan yang berpola khas.

Secara garis besar bentuk permukiman yang berpola khas dapat dibedakan menjadi dua yaitu permukiman berpola teratur dan permukiman berpola tidak teratur. Hudson (1970, dikutip dari Wesnawa 2015, hal. 64) menjelaskan bahwa permukiman berpola teratur terbentuk dari dusun-dusun atau bangunan-bangunan rumah yang lebih kompak dengan jarak tertentu, sedangkan permukiman berpola tidak teratur terdiri dari dusun-dusun atau bangunan rumah yang tersebar dengan jarak tidak tertentu.

Shryock, et.al (1971, dikutip dari Wesnawa 2015, hal. 66) mengemukakan secara garis besar terjadinya variasi dari bentuk pola permukiman dipengaruhi oleh faktor fisik baik alami maupun buatan, faktor sosial ekonomi dan faktor sosial budaya manusia. Selain itu, variasi pola permukiman dapat pula terbentuk karena pertimbangan dalam penentuan lokasi rumah dan persebaran penduduk. Pola permukiman di setiap wilayah dapat diidentifikasi melalui regionalisasi, kategori atau klasifikasi tipe dari tempat tinggal. Namun demikian, identifikasi tersebut tidak mudah dilakukan, perlu suatu pendekatan yang komprehensif untuk dapat mengkaji kekhasan permukiman pada tiap wilayah.

Salah satu indikator fisik yang dapat diidentifikasi pola permukimannya adalah dari kenampakan bentuk kota, contohnya adalah di Palembang. Kota Palembang memiliki bentuk kota yang kompak. Hal ini dapat diidentifikasi melalui kenampakan perairan yang cukup lebar membelah kotanya yang seolah-olah kota tersebut terdiri dari dua bagian yang terpisah (split cities) (Heldayani, 2017, hal. 5-6).

Seperti kasus pada permukiman di sepanjang Sungai Ogan. Sungai Ogan adalah cabang dari Sungai Musi. Posisi Sungai Ogan mengalir melewati administrasi Kota Palembang bagian Seberang Ulu. Popularitas Sungai Ogan tidak sepopuler Sungai Musi. Sungai Ogan memiliki potensi dan permasalahan yang khas. Khas yang dimaksud adalah posisi permukiman yang berdekatan dengan sungai tetapi matapencariannya bukanlah nelayan, melainkan isinya adalah para pengrajin kain dan penjual kemplang.

Terkait dengan gejala tersebut perlu suatu bidang ilmu untuk mengkaji dari sudut pandang geografi untuk mengetahui karakteristiknya yang terdiri atas; Sebaran Bangunan Rumah, Orientasi Bangunan Rumah dan Kepadatan Bangunan Rumah, tujuannya agar kelurahan ini dapat diidentifikasi kekhasan wilayahnya. 
Pada penelitian ini, peneliti tertarik mengidentifikasi karakteristik permukiman dengan memanfaatkan Sistem Informasi Geografi (SIG) di Kelurahan 1 Ulu, Kecamatan Seberang Ulu 1, Kota Palembang. Harapannya hasil penelitian dapat menambah kekhasan pengembangan ilmu geografi kehususnya bidang geografi permukiman.

\section{METODE PENELITIAN}

Dalam rangka memahami karakteristik permukiman di daerah perkotaan Kota Palembang maka lokasi pengamatan yang relevan pada penelitian ini di Kelurahan 1 Ulu, Kecamatan Seberang Ulu 1, Kota Palembang. Daerah ini merupakan kawasan strategis di tepian Sungai Ogan. Permukiman di Kelurahan 1 ulu ini merupakan kawasan sektor industri baru yang berasal dari bidang pengrajin kain dan pembuat kemplang.

Penelitian ini menggunakan metode survei dengan Pengumpulan data dilakukan dengan teknik interpretasi citra dan observasi. Interpretasi Citra berupaya untuk mengenali obyek yang tergambar pada citra.Pengenalan obyek yang tergambar pada citra, terdapat tiga rangkaian kegiatan yang diperlukan, yaitu deteksi, identifikasi, dan analisis.

Untuk mendeteksi, mengidentifikasi, dan menilaii interpretasi visual yang mana, peneliti memilih 3 unsur utama interpretasi yaitu pola, bentuk dan asosiasi untuk mengetahui arti pentingnya obyek yang tergambar pada citra. Sedangkan observasi digunakan penelitian untuk melihat perilaku manusia, proses kerja, gejala-gejalaalam yang diamati.

Teknik Analisis Data dilakukan dengan pendekatan keruangan. Variabel pertama, Sebaran Bangunan Rumah peneliti menggunakan model dan analisis tetangga terdekat atau nearest neighbour analysis dengan rumus:

$$
R=\frac{\mathrm{D}_{\mathrm{obs}}}{\mathrm{D}_{\exp }}
$$

$$
D_{\text {exp }}=\frac{1}{2 \sqrt{\mathrm{A}}}
$$

Sumber: Haggett (1983, hal. 363). Variabel kedua, Orientasi Bangunan Rumah menggunakan interpretasi citra dengan melakukan interpretasi visual meliputi 3 unsur utama yakni pola, bentuk, dan asosiasi. Dan variabel ketiga, Kepadatan Bangunan Rumah menggunakan rumus kepadatan bangunan meliputi 4 kelas (sangat tinggi, menengah/sedang, rendah dan sangat rendah):

$$
K D B=\frac{\text { Jumlah Bangunan }}{\text { Luas Area }}
$$

\section{HASIL PENELITIAN DAN PEMBAHASAN}

Kegiatan penelitian di Kelurahan 1 Ulu dikelompokkan menjadi 4 zona berdasarkan batas fisik yaitu jalan, 4 zona terdiri dari Zona 1, Zona 2, Zona 3 dan Zona 4. Adapun yang diamati pada zona tersebut adalah pertama, sebaran bangunan rumah untuk mengetahui pola permukiman. Kedua, orientasi bangunan rumah untuk mengetahui orientasi pintu atau arah yaitu orientasi darat atau orientasi sungai. Ketiga, kepadatan bangunan rumah untuk mengetahui kondisi jumlah permukiman di kelurahan 1 ulu tersebut.

\section{Lokasi Penelitian}

\section{Sebaran Bangunan Rumah}

Sebaran Bangunan Rumah pada penelitian ini menggunakan NNA (Nearest Neighbour Analysis) untuk pengolahan analisis data.

Penggunaan teknik analisis tetangga terdekat atau nearest neighbour analysis adalah untuk menentukan polanya tergolong kriteria pola mengelompok, pola acak, dan pola tersebar merata.

Untuk mengetahui apakah pola permukiman yang dianalisis, termasuk mengelompok, random atau seragam dibandingkan dengan kontinum nilai parameter tetangga terdekat $\mathrm{R}$ untuk masing pola yang dapat diperlihatkan:

$$
\begin{aligned}
& \mathrm{R}=0-0,7 \text { pola bergerombol/mengelompok } \\
& \mathrm{R}=0,71-1,4 \text { pola acak } \\
& \mathrm{R}=1,41-2,15 \text { pola tersebar merata }
\end{aligned}
$$




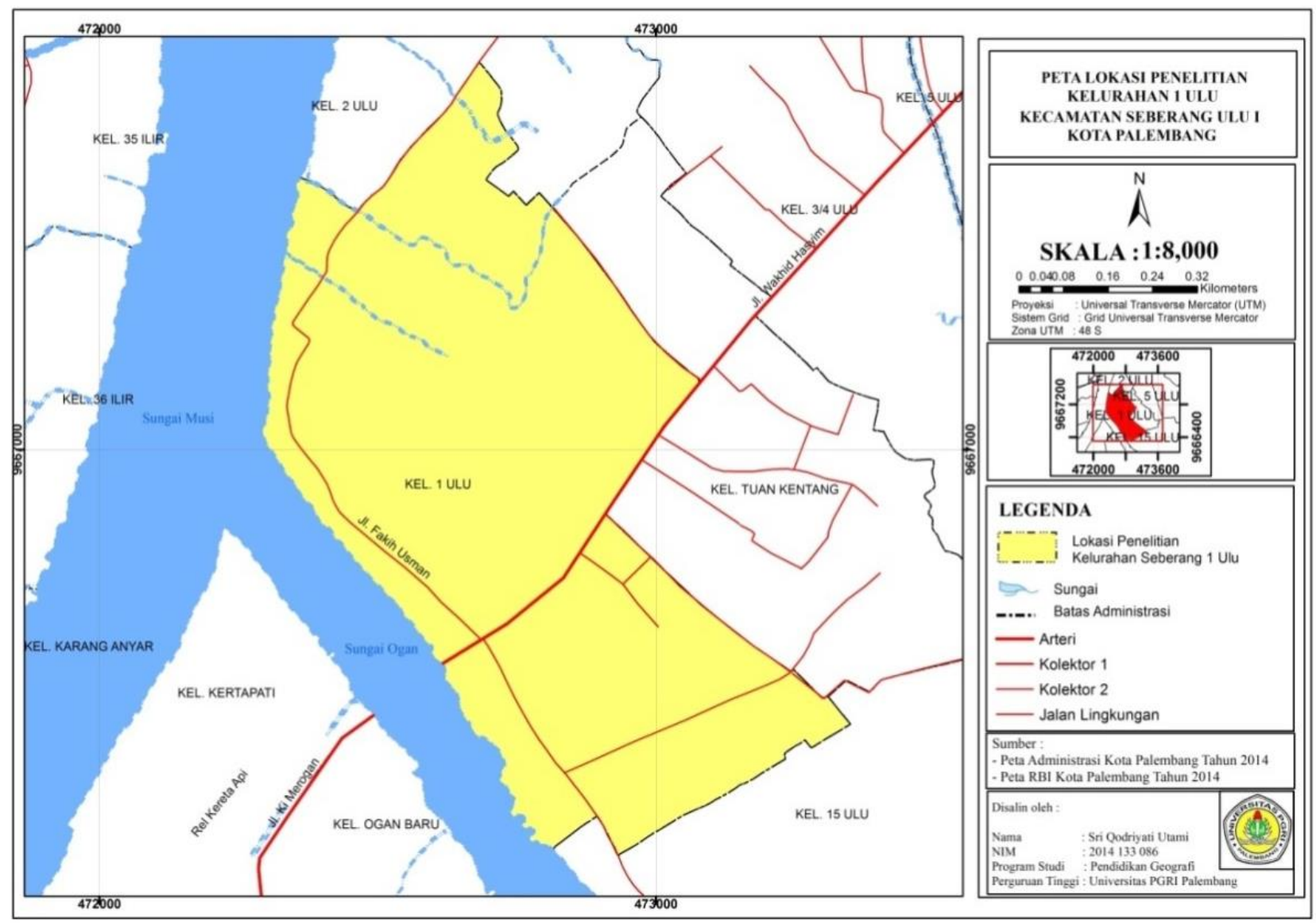

Sumber: Lutfi (2012, hal.72)

Gambar 1. Peta Kelurahan 1 Ulu Kecamatan Seberang Ulu 1 Kota Palembang

Setelah penggunaan teknik analisis data selanjutnya peneliti mengkriteriakan pola sesuai hasil analisis tetangga terdekat setiap zona wilayah. Dapat ditunjukkan pada tabel 1.

\section{Orientasi Bangunan Rumah}

Orientasi bangunan rumah adalah peninjauan untuk menentukan arah pintu rumah yang mendasari budaya dan adat kebiasaan masyarakat setempat.

Perkembangan orientasi suatu kawasan akan mempertimbangkan aspek fungsional dan aksesibilitas untuk penentu orientasinya (Suprijanto, 2001, dikutip dari Purnama 2015, hal.12).

Tabel 1. Analisis Tetangga Terdekat Di Kel. 1 Ulu

\begin{tabular}{ccc} 
Zona Wilayah & Hasil Analisis Tetangga Terdekat & Pola \\
Zona I & 1,001401 & Pola Acak/Random \\
\hline Zona II & 0,621006 & Pola Mengelompok \\
Zona III & 1,0225455 & Pola Acak/Random \\
Zona IV & 1,175806 & Pola acak/Random \\
\hline
\end{tabular}




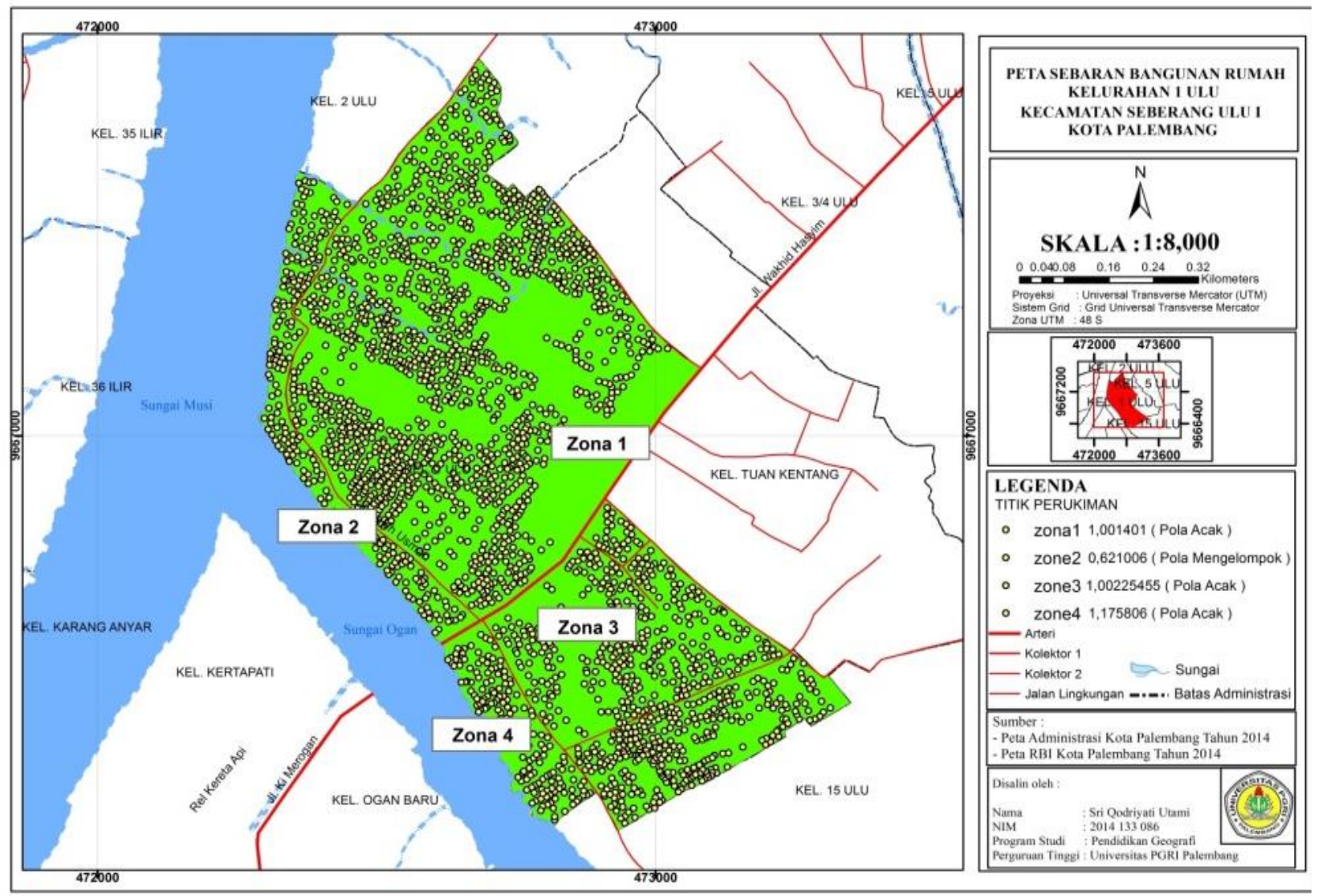

Gambar 2: Peta Sebaran Bangunan Rumah di Kelurahan 1 Ulu, Kecamatan Seberang Ulu 1, Kota Palembang

Gambar 2 berikut diatas adalah peta sebaran bangunan rumah di daerah Kelurahan 1 Ulu, Kecamatan Seberang Uli 1, Kota Palembang setelah menggunakan teknik analisis tetangga terdekat.
Pada tabel 2 berikut ini menjelaskan mengenai orientasi permukiman berdasarkan asosiasi obyek di Kelurahan 1 Ulu :

Tabel 2. Orientasi Permukiman Berdasarkan Asosiasi Obyek Di Kelurahan 1 Ulu

\begin{tabular}{ccc}
\hline \multirow{2}{*}{ Zona } & \multicolumn{2}{c}{ Asosiasi } \\
\cline { 2 - 3 } & Orientasi Darat & Orientasi Sungai \\
\hline Zona I & $100 \%$ & $0 \%$ \\
\hline Zona II & $66,97 \%$ & $33,02 \%$ \\
\hline Zona III & $100 \%$ & $0 \%$ \\
\hline Zona IV & $95,30 \%$ & $4,68 \%$ \\
\hline
\end{tabular}

Peneliti mendapatkan hasil penelitian yang real dari lapangan mengenai orientasi bangunan rumah. Dimana zona 1 arah pintu orientasi darat sebanyak 1330 rumah dengan pesenan $100 \%$, zona 2 arah orientasi darat sebanyak 217 rumah dengan 66,97\% dan
Sumber: Olah data, 2018

orientasi sungai sebangyak 72 rumah dengan $33,02 \%$, zona 3 arah orientasi darat sebanyak 631 rumah dengan $100 \%$, zona 4 arah pintu orientasi darat sebanyak 142 rumah dengan $95,30 \%$ dan orientasi sungai sebanyak 6 rumah rumah dengan $4,68 \%$. 
Diagram 1. Orientasi Bangunan Rumah Di Kel. 1 Ulu

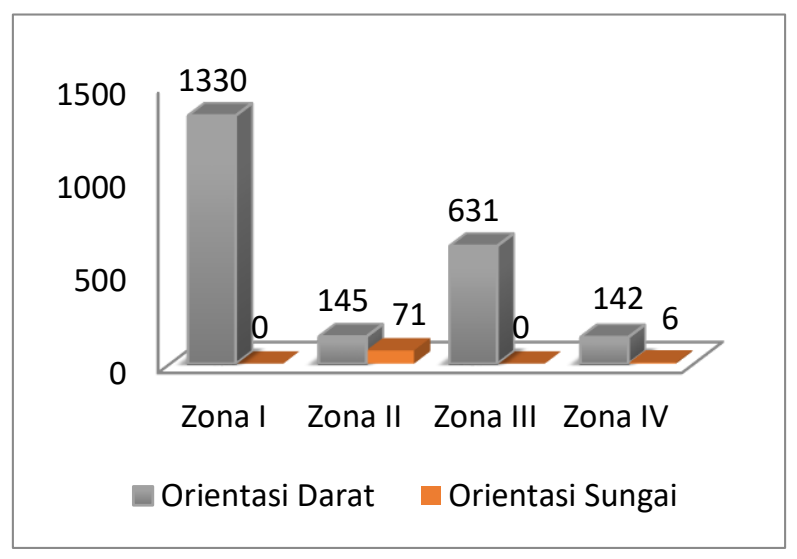

Sumber: Olah data, 2018

Dari diagram 2 tersebut dapat ditarik kesimpulan bahwa orientasi bangunan rumah di Kelurahan 1 Ulu, Kecamatan Seberang Ulu 1, Kota Palembang Orientasi darat lebih mendomisili dari pada orientasi sungai dengan jumlah 2251 bangunan rumah dengan $96,60 \%$ dari pada orientasi sungai dengan jumlah 79 persenan $3,40 \%$.

Diagram 2. Orientasi Bangunan Rumah Di Kel. 1 Ulu

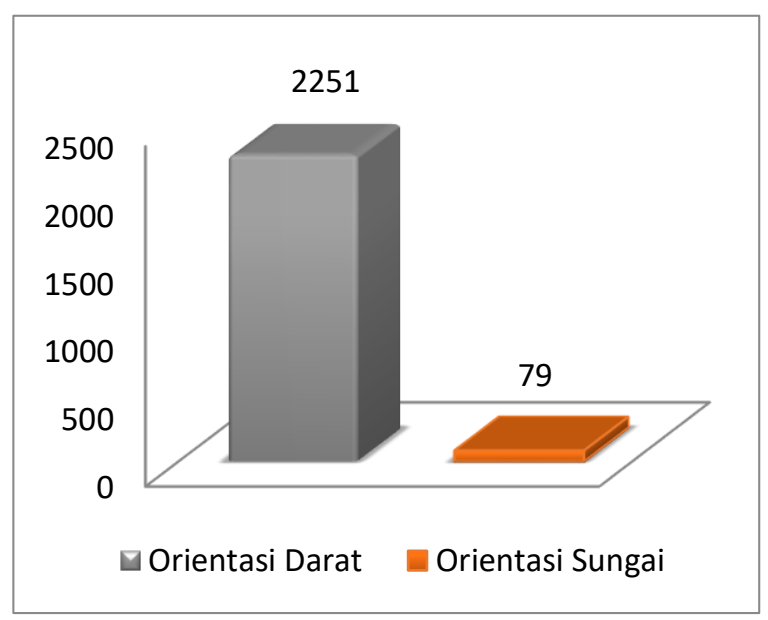

Sumber: Olah data, 2018

\section{Kepadatan Bangunan Rumah}

Kepadatan Bangunan Rumah masyarakat Kelurahan Ulu 1. Pada penelitian ini peneliti mendapatkan hasil penelitian yang berasal dari Citra Quickbird dan juga Arcgis

Dari tabel diatas dapat diketahui, Kepadatan Bangunan Rumah dari sudut pandang kedua yakni dari unit analisis detail lebih memperlihatkan lebih detail dan rinci perzona dari pada keseluruhan kepadatan di Kelurahan 1 Ulu. Beikut diagram analisis untuk mengetahui kepadatan setiap zona nya kedalam kriteria kepadatan.

Hasil penelitian yang berasal dari citra Quickbird dan arcgis dikelola dengan perhitungan kepadatan. Menurut Lutfi (2012, hal. 72) perhitungannya persentase perbandingan antara jumlah bangunan dengan luas tanah perpetakan/ daerah perencanaan $=($ Jumlah bangunan $/$ Luas area $)$ dengan klasifikasi kriteria kurang dari 5\% KDB sangat rendah, 5\% sampai dengan $20 \%$ KDB rendah, $20 \%$ sampai $75 \%$ KDB menengah/sedang, dan lebih besar dari 75\% KDB sangat tinggi. Peneliti membagi menjadi 2 sudut pandang, pertama kepadatan bangunan dengan unit analisis kecamatan. Berikut adalah tabel 3 kepadatan permukiman di Kelurahan 1 Ulu:

Tabel 3. Kepadatan Permukiman Di Kel. 1 Ulu

\begin{tabular}{ccc}
\hline $\begin{array}{c}\text { Jumlah } \\
\text { Bangunan }\end{array}$ & $\begin{array}{c}\text { Luas Zona } \\
\text { Wilayah }\end{array}$ & Kepadatan \\
\hline $\mathbf{2 3 2 6}$ & 68 Ha & $34,20 \%$ \\
\hline \multicolumn{3}{c}{ Sumber: Olah Data, 2018 }
\end{tabular}

Dari sudut pandang kedua yakni unit analisis Kelurahan dari seluruh jumlah bangunan dari zona 1 sampai dengan zona 4 yang berjumlah 2326 kemudian dibagi dengan jumlah keseluruhan luas wilayah dalam satuan Ha yakni 68 Ha didapatkan hasil KDB 34,20\% yang termasuk kriteriamenegah atau sedang. Berikut adalah tabel 4 tentang kepadatan bangunan rumah dengan unit analisis yang lebih detail di masing-masing zona:

Tabel 4. Kepadatan Bangunan Rumah Dengan Unit Analisis Lebih Detail Di Kel. 1 Ulu

\begin{tabular}{ccc}
\hline Zona & KDB \% & Kriteria \\
\hline Zona I & $19,5 \%$ & Rendah \\
\hline Zona II & $3,19 \%$ & Sangat Rendah \\
\hline Zona III & $9,27 \%$ & Rendah \\
\hline Zona IV & $2,17 \%$ & Sangat Rendah \\
\hline \multicolumn{3}{c}{ Sumber: Olah Data, 2018 }
\end{tabular}

kepadatan bangunan rumah secara detail di Kelurahan 1 Ulu: 
Diagram 3. Analisis Kepadatan Bangunan Rumah Secara Detail Di Kel. 1 Ulu

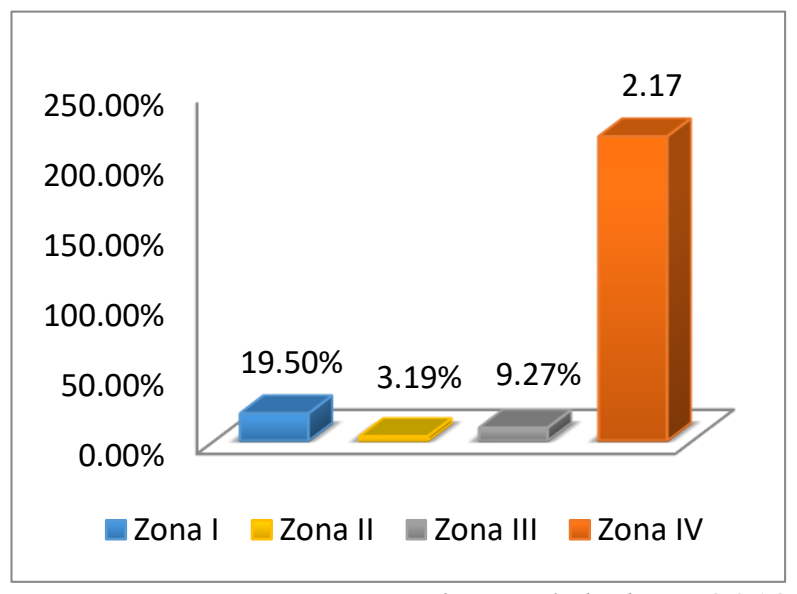

Sumber: Olah data, 2018
Dari diagram 3 dapat diketahui bahwa kepadatan bangunan rumah secara detail memiliki dua variari yakni sangat rendah dan juga rendah, dapat dilihat di zona 1 dengan KDB 19,5\% termasuk ke kriteria kepadatan rendah, zona 2 dengan KDB 3,19\% termasuk ke kriteria kepadatan sangat rendah, zona 3 dengan KDB 9,27\% termasuk kriteria kepadatan rendah, dan zona 4 dengan KDB $2,17 \%$ termasuk kriteria sangat rendah. Dari hasil penelitian ketiga variabel tersebut peneliti membuat tabel karakteristik permukiman di Sungai Ogan untuk mendapatkan jawaban dari permasalahan dalam penelitian sebagai yakni berikut:

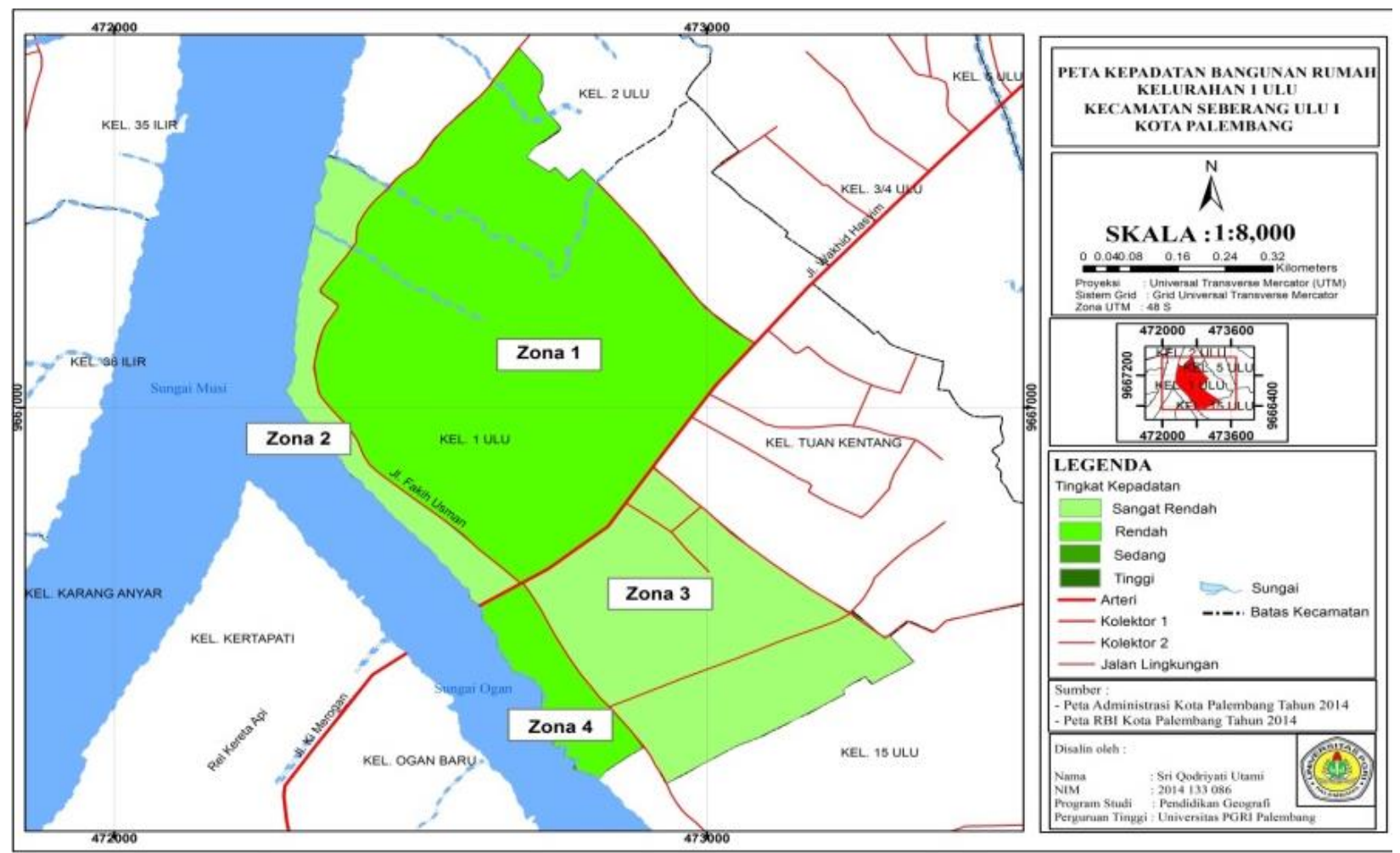

Gambar 3. Peta Kepadatan Bangunan Rumah di Kelurahan 1 Ulu, Kecamatan Seberang Ulu 1, Kota Palembang

Tabel 5. Karakteristik Permukiman Di Sungai Ogan

\begin{tabular}{cccc}
\hline Wilayah & $\begin{array}{c}\text { Sebaran Bangunan } \\
\text { Rumah }\end{array}$ & $\begin{array}{c}\text { Orientasi Bangunan } \\
\text { Rumah }\end{array}$ & $\begin{array}{c}\text { Kepadatan } \\
\text { Bangunan Rumah }\end{array}$ \\
\hline Zona 1 & Pola Acak/Random & Orientasi Darat & Rendah \\
\hline Zona 2 & Pola Mengelompok & Orientasi Darat & Sangat Rendah \\
\hline Zona 3 & Pola Acak/Random & Orientasi Darat & Rendah \\
\hline Zona 4 & Pola Acak/Random & Orientasi Darat & Sangat Rendah \\
\hline & & & Sumber: Olah data, 2018
\end{tabular}


Pada penelitian ini peneliti menemukan sebuah ciri khas ataupun karakteristik permukiman yang ada di Kelurahan 1 Ulu, Kecamatan Seberang Ulu 1, Kota Palembang.

Variabel pertama yakni Sebaran Bangunan Rumah hasil analisis tetangga terdekat atau nearest neighbour analysis dari teori Haggett diketahui bahwa sebaran bangunan rumah di Kelurahan 1 Ulu memiliki 2 variasi pola permukiman yakni, Zona 1, Zona 2, dan Zona 4 merupakan pola permukiman Acak/Random, sedangkan Zona 2 merupakan pola permukiman Mengelompok hal ini terjadi karena pada zona 2 wilayahnya merupakan kawasan paling lama masyarakat kelurahan 1 ulu pertama bertempat tinggal pada kawasan ini hal ini lah yang mempengaruhi hanya zona 2 yang memiliki pola permukiman mengelompok.

Variabel kedua yakni Orientasi Bangunan Rumah peneliti mendapatkan hasil dilapangan bahwa permukiman di Kelurahan 1 Ulu, Kecamatan Seberang Ulu 1, Kota Palembang 96,60\% orientasi darat atau bisa disebut bahwa arah pintunya menghadap kejalan bukan kesungai. Menurut teori dari Suprijanto (2001, dikutip dari Purnama 2015, hal.12) yang menyatakan bahwa perkembangan orientasi suatu kawasan akan mempertimbangkan aspek fungsional dan aksebilitas untuk penentu arah orientasinya merupakan teori yang benar dalam penelitian ini karena faktor pada zona 2 dan zona 4 ini dahulunya akses transportasinya melalui sungai namun dengan adanya perubahan dibangunnya jalan masyarakat cenderung berubah orientasinya menjadi darat dan lama kelamaan transportasi sungai pada kedua zona ini mulai sedikit karena beralih fungsi transportasi.

Variabel ketiga yakni Kepadatan Bangunan Rumah di Kelurahan 1 Ulu, Kecamatan Seberang Ulu 1, Kota Palembang pada variabel ini peneliti membagi menjadi 2 sudut pandang yakni pertama kepadatan bangunan dengan unit analisis kecamatan dengan hasil KDB 34,20\% yang termasuk kekriteria menegah atau sedang, kedua kepadatan bangunan dengan unit analisis lebih detail blok permukiman dengan hasil zona 1 dengan KDB 19,5\% termasuk ke kriteria kepadatan rendah, zona 2 dengan KDB 3,19\% termasuk ke kriteria kepadatan sangat rendah, zona 3 dengan KDB 9,27\% termasuk kriteria kepadatan rendah, dan zona 4 dengan KDB $2,17 \%$ termasuk kriteria sangat rendah.

Hal ini dipengaruhi oleh faktor umur sebuah permukiman, Zona 1 dan Zona 3 merupakan wilayah dengan luas wilayah yang besar namun karena tempat yang strategis membuat masyarakat lebih banyak memilih bertempat tinggal diwilayah zona 1 dan zona 3 ini. Sebaliknya pada zona 2 dan zona 4 merupakan wilayah dengan masyarakatnya sudah lama bertempat tinggal diwilayah tersebut sehingga mereka walaupun pada zona 2 dan 4 ini rawan terjadinya pasang yang membuat keadaan disekitar banjir tetap membuat masyarakat bertempat tinggal disana karena mereka terbiasa tidak hanya memakai transportasi darat saja namun untuk transportasi sungai mereka bisa.

\section{SIMPULAN}

Berdasarkan hasil penelitian dan pembahasan mengenai karakteristik permukiman di Kelurahan 1 Ulu, Kecamatan Seberang Ulu 1, Kota Palembang dapat diambil kesimpulannya bahwa, Pertama pada sebaran bangunan rumah ada dua variasi pola sebaran yaitu Zona 1, Zona 3, Zona 4 merupakan Pola Permukiman Acak dan Zona 2 merupakan Pola Permukiman Mengelompok. Kedua, yakni Orientasi Bangunan Rumah di Kelurahan 1 Ulu memiliki dua vaiasi yakni arah orientasi darat dan orientasi sungai. Namun, pada kelurahan 1 ulu Orientasi darat lebih mendominasi dari pada orientasi sungai dengan jumlah 2251 persentase $96,60 \%$ dari pada orientasi sungai dengan jumlah 79 persentase 3,40\%. Ketiga, yakni Kepadatan Bangunan Rumah yang memiliki dua variasi yakni rendah dan sangat rendah zona 1 dengan KDB 19,5\% termasuk ke kriteria kepadatan rendah, zona 2 dengan KDB 3,19\% termasuk ke kriteria kepadatan sangat rendah, zona 3 dengan $\mathrm{KDB}$ 9,27\% termasuk kriteria kepadatan rendah, dan zona 4 dengan KDB 2,17\% termasuk kriteria sangat rendah. Hal ini terjadi dikarenakan faktor permukiman berdekatan dengan sungai, usia permukiman dan faktor transportasi serta aksebilitas. 


\section{DAFTAR PUSTAKA}

Badan Pusat Statistik. (2017). Kecamatan Seberang Ulu 1 Dalam Angka 2017. Palembang: CV Alief Media Grafika.

Bambang Wicaksono, Ari Siswanto, Susilo Kusdiwanggo, Anwar, Febrianti Fransiska febri, 2016. Cultural Approach of sustainability in dwellings Cultural Riparian Community Musi River Palembang, Journal of architectureand built Environment, Vol 43, No. 2, December, 2016.

Daldjoeni.(2017). Geografi Kota dan Desa. Yogyakarta: Ombak.

Depdikbud.(2008). Kamus Besar Bahasa Indonesia Edisi Keempat. Jakarta: Balai Pustaka.

Farizki M, WenangAnurogo, 2017. Pemetaan Kualitas Permukiman dengan Menggunakan Penginderaan Jauh dan SIG di Kecamatan Batam Kota Batam, Majalah Geografi Indonesia, Vol 31, No.1, Maret 2017 (39 - 45).

Hagget Peter, (1983). Geography: A Modern Synthesis. Harper and Row: London.

Hamidah Noor, Rijanta. R, Setiawan Bakti, Marfai Aris Muh, 2016. Analisis Permukiman Tepian Sungai yang Berkelanjutan Kasus Permukiman Tepian Sungai Kahayan Kota Palangkaraya, Jurnal INERSIA, Vol. XII, No. 1, Mei, 2016.

Hamidah Noor, Rijanta. R, Setiawan Bakti, Marfai Aris Muh, 2017. Physical Analysis of formal and informal integration In Urban Riverside Settlement. Journal Mimbar, Vol. 33, No. 1, June, 2017.

Heldayani Eni, Idris Muhammad, Sukardi. 2017. Proses Terbentuknya Permukiman Etnis di Kota Palembang. Jurnal Pendidikan Geografi ULM, Vol 4 No 6, November,2017.
Heldayani Eni, Ritohardoyo Su, Widiyastuti Dyah, 2015. Pola Persebaran Perumahan Menurut Kelompok Etnis di Kelurahan Kuoto Batu, Kota Palembang. Majalah Geografi Indonesia, Vol.29 No.1, Maret, 2015.

Indrawan, dkk.(2016). Metodologi Penelitian Kuantitatif, Kualitatif, dan Campuran untuk Manajemen, Pembangunan, dan Pendidikan. Bandung: PT. Refika Aditama.

MartonoAgusDwi, (2013). Metode Pengambilan Sample Untuk Penelitian Geografi. Yogyakarta: Ombak.

Muta'ali Lutfi, (2012). Daya Dukung Lingkungan Untuk Perencanaan Pengembangan Wilayah. Yogyakarta: Badan Penerbit Fakultas Geografi (BPFG) Universitas Gadjah Mada.

Purnama Dina, 2015. Pola Permukiman dan Orientasi Hunian Masyarakat di Pinggiran Sungai Siak. Departemen Arsitektur, Universitas Sumatera Utara.

Putro Dwijo Jawas, Nurhamsyah. M, 2014. Pola Permukiman Tepian Air. Studi Kasus: Desa Sepuk Laut, Punggur Besar, dan Tanjung Saleh Kecamatan Sungai Kakap, Kabupaten Kuburaya, Journal Langkau Betang, Vol. 2, No. 1. 2014.

Sangalang Indrabakti, Adji. F Fredyantoni, 2014. Pengaruh Kondisi Hunian dan Lingkungan Terhadap Keberlanjutan Permukiman Tepi Sungai. Studi kasus: Kampung Pahandut dan Desa Danau Tundai di Kota Palangkaraya, Jurnal Perspektif Arsitektur, Vol. 9, No. 2, Desember, 2014.

Slamet teguh. (2009). Pola Permukiman. Retrieved from Http://slametteguh.blogspot.co.id/2009/ 02/pola-permukiman.html? $\mathrm{m}=1$.

Sugiyono.(2016). Metode Penelitian Pendidikan. Bandung: Alfabeta. 
SuryantoroAgus. (2013). Intergrasi Aplikasi Sistem Informasi Geografis Dukungan Bahasa Pemprograman dan Basis data Relational Dalam Penyusunan Program Aplikasi Berbasis SIG. Yogyakarta: Ombak.

Sutanto.(1992). Penginderaan Jauh. Yogyakarta: Gadjah Mada University Press.
Wesnawa Astra I gede.(2015).Geografi Permukiman. Yogyakarta: Graha Ilmu.

Yunus, Hadi Sabari. (2008). Manajemen Kota Perspektif Spasial. Yogyakarta: Pustaka Pelajar.

Yunus, Hadi Sabari. (2016). Metodologi penelitian wilayah kontemporer. Yogyakarta: Pustaka Pelajar. 